\title{
How to Build a 'Beautiful China' in the Anthropocene. The Political Discourse and the Intellectual Debate on Ecological Civilization
}

\author{
Maurizio Marinelli ${ }^{1}$ (D) \\ Published online: 22 February 2018 \\ (C) The Author(s) 2018. This article is an open access publication
}

\begin{abstract}
The aim of this article is to contribute to the debate on global prosperity in the post-GDP world, with specific attention given to the political discourse and intellectual debate on ecological civilization in China. I will first assess the national and international implications of assuming that China as a whole is a 'locality'. I will then focus specifically on one of the most significant political and intellectual debates in Chinese studies today, namely the social and environmental challenges linked to China's political and socioeconomic development. In this light, I will engage with the debate on the Anthropocene - the era during which humans have become an earth-altering force - and its interrelationship with the discourse on ecological civilization. In China, the term 'ecological civilization' appeared in the 1980s in the academic domain and was then appropriated by political discourse. This article proves that the concept of eco-civilization, in a similar way to the Anthropocene, has a significant discursive power: it allows for a shift from the binary political economy discourses of 'growth' versus 'development', and 'socialism' versus 'capitalism', to the inquiry of eco-socially sustainable prosperity. The final aim of this article is both to offer a more nuanced analysis of the relationship between the political discourse and academic debate, and to substantiate the rhetoric trope of 'Advancing Ecological Civilization and Building a Beautiful China'.
\end{abstract}

Keywords Ecological civilization · Governance $\cdot$ Prosperity $\cdot$ Anthropocene $\cdot$ Beautiful China

Maurizio Marinelli

M.Marinelli@sussex.ac.uk

1 University of Sussex, Brighton, UK 
In history, the greatest mistake committed by mankind lies in the search for quick success, excessive revelling in one's immediate interests, greedy, brutal, and savage plundering of nature, destruction of ecological balance, and (ultimately) destruction of our own living environment.

Ye Qianji [68].

\section{China as a Locality: A Place of Knowledge Production}

A premise is necessary to better understand the context of the Chinese Government's project that goes under the name of 'ecological civilization construction' [from now on: eco-civilization]. This project, as well as the relevant debate, originated in China under specific circumstances, which have to do both with the way in which China has positioned itself since the early 1980s, and also with the planetary narratives foregrounding China as a specific locality.

The term 'locality' embodies a highly elusive conceptual range of significance, since its definition varies according to the context in which it is used. Broadly speaking, 'locality' is employed to indicate a particular geographical area, such as a neighbourhood or a district in a city, but locality also indicates the quality of having a position in space. In both senses, when one refers to China, the use of the term locality raises a series of hermeneutic questions. The crucial issue can be formulated as follows: Can China be seen as a locality, in the sense of a cultural, political and epistemological construct, which has both a precise geographical connotation and a geopolitical selfpositionality? The analysis of this question constitutes a necessary premise for this article, whose final aim is to analyse the current political discourse, ${ }^{1}$ as well as the relevant intellectual debate, on ecological civilization in China and its possible relevance for the debate on global prosperity in the Anthropocene.

In a thought-provoking article, political geographer John Agnew argues that there are two dominant geopolitical narratives about China's place in the world. The first one tends to see China as converging towards a repetition of the Western experience (e.g. hegemonic power or nation-state), while the second one tends to insist on China's exceptionalism, seeing China as an entity heading towards the creation of a Chinacentric new world order [1]. According to Agnew, the main issue at stake with these two narratives is that both these positions 'erase the significance of China's past for the country's leaders and population as they come to terms with their new place in the world' ([1]:302). Therefore, Agnew insists on the importance of re-reading the past, and he makes a number of telling points. One of them interests me in particular here: he upholds "the view that China's opening to the world represents a "timespace crisis" in the sense that China can no longer be set in an eternally present and geographically contained world but must be increasingly externally oriented and dynamic, drawing ideas both from abroad but also from what had been "lost" with the official disavowal of the past China from before the 1949 Revolution' ([1] 302). In other words, Agnew argues, "the geographical and historical limits of "China" are undergoing a fundamental redefinition' ([1]:302). He also points out that 'the various stories told about China's

\footnotetext{
${ }^{1}$ For more on political discourse, see Lutgard Lams' article in this special issue. Cp. also Cao et al. [6].
} 
historical past and Chinese geographical presence today (and how they relate to China's place in the world) emanate from discrete sites or venues inside China. They are overwhelmingly the output of policy entrepreneurs and intellectuals in institutes, universities, and think tanks in Beijing' ([1]:303). Therefore, Agnew insists that it important 'To speak of "places" of knowledge production', which of course means 'to invoke much more sociologically meaningful but also typically localized sites where local, national, and long-distance influences on thinking and research practice' come together $([1]: 303-4){ }^{2}{ }^{2}$

The crux of the matter is, following Agnew's poignant remarks, that the problem with seeing China as a whole as a locality involves a crucial methodological and theoretical question, which relates specifically to the alleged, and often conveniently assumed, single identity of the present day geo-body that we refer to as China. The size, the geomorphological features, the cultural and ethnic diversity, not to mention the scale and speed of economic transformation in the different provinces and municipalities, have had and are still having a significant impact on the discourse on the environment in China and, of course, also on the politics of resources and their distribution in relation to what is the declared key Government concern of ensuring ecological security and sustainable development. Going beyond simplistic attempts to portray China as one 'civilizational state (wenming guojia)' $[25,26]]^{3}$ the question regarding the complex, multi-faceted and multi-layered identity of 'China' remains a subject of contention both inside and outside China.

In this article, I intend to build on Agnew's premise, not assuming China per se as a 'locality', but using the concept of locality to refer to the self-positionality of China. This provides the means to identify and examine the places of knowledge production of the major contributors to the debate on eco-civilization, adding to the analysis of the master narrative emerging from the political establishment, the relevant intellectual articulations on this theme.

\section{Ecological Civilization and Global Prosperity}

Approaching the term locality from the perspective of China's positionality in terms of global governance, reveals an often concealed 'timespace crisis'. Thus, I agree with Agnew that China 'can no longer be set in an eternally present and geographically

\footnotetext{
${ }^{2}$ Cp. also: Agnew and Livingstone [2]; Livingstone [36].

${ }^{3}$ Martin Jacques praises China as a long-standing 'civilizational-state', arguing that China has been uninterruptedly unified for two thousand years, benefitting from a common language, a common culture (based on Confucian values and ancestral worship), and a single-ethnic identity. According to Jacques, the priority of the State is to maintain the alleged unity, cohesion and integrity of the Chinese civilization that the State embodies. Unsurprisingly, this syllogism has received a very positive reception in China. Jacques' argument that China is not a nation state, but a civilizational state, simplistically antagonises the master narrative of the 'rise of the West', as primarily shaped by the individual experiences of rising nations, to the 'peaceful rise of China'. Jacques' assertion that China has been 'moulded by its sense of civilization', ergo the state is the embodiment of this civilization, is an a-historical assertion that contributes to the hubristic logic of the 'clash of civilizations' without considering the counter-argument that a civilization is not necessarily a self-enclosed entity, but more porous, fluid, and open to wider influences which can contribute to its development over time. ([40]:301). For another angle on 'wenming' with regard to the ideational governance in Xinjiang, see Ondřej Klimeš's article in this special issue.
} 
contained world' ([1]:302), but I also intend to build on that realisation, and first of all develop the idea that, with regard to eco- civilization, one of the main characteristics of the discourse set by the political establishment is its projective temporality, characterised by what I define as future perfect tense, since the political documents seem to contain a recurring projection of perfection into an allegedly perfect future. This can be read as being in line with 'The China Story': the master narrative which was, in cultural historian Geremie Barmé's words, 'devised as part of or, at least, under the umbrella of creating a foundational narrative for the political purpose of nationbuilding' [3]. I would add that this is the story of a locality and a positionality: an alleged singular 'story', in which China is presented as a unified, ontogenetic civilization that developed accordingly to a linear, rational and almost mechanically instantiated teleology. Barmé poignantly emphasises that the China Story reifies and reiterates the success story of the Party-State. In this sense, it can be seen as the unique - and unilateral - story of a locality which tries to conceal the 'timespace crisis', since it is not situated in the present, but in the future perfect tense. I refer here to the particular form or construction which is used to describe an event that is expected to happen before a time of reference in the future. This form, which seems to be inherent to the Chinese political formulations on eco-civilization, combines the projection into the future with the assumption of a perfect aspect that views an event as completed a priori and therefore indicative of progress.

I would also like to go one step further with regard to 'timespace crisis', and argue that the intellectual debate on eco-civilization is strictly interconnected with the global discourse on the Anthropocene, since the discussion on eco-civilization, eschewing the previously upheld development model that had seen economic growth take priority over environmental health, is focused on the relationship between man and nature in a way which both echoes and integrates the academic debate on the Anthropocene. The Anthropocene is defined as the geological period in which the effect of human activities on nature reaches an unprecedented level and has a significant global impact on the earth's eco-systems [4, 51]. Atmospheric chemist and Nobel Laureate Paul J. Crutzen and biologist Eugene F. Stoermer linked this 'new geological era', entirely dominated by human activity over nature -'human dominance of biological, chemical and geological processes on Earth' -, to the Industrial Revolution which took place in late eighteenth Century Europe ([12, 13]:360). The Anthropocene concept emerged at a time of a 'dawning realization that human activity was indeed changing the Earth on a scale comparable with some of the major events of the ancient past.' ([70], p. 2228). A fundamental tenet is that: 'The deep intertwining of natural and human systems is at the heart of the scientific Anthropocene narrative' [43]. This is also at the centre of the debate on eco-civilization in China.

One could argue that the discourse on the Anthropocene as an ideological, ontological and epistemological standpoint has three main characteristics: 1) it emphasizes the role of human activities and their impact on nature; 2) it calls into question the economy of growth; 3) it allows us to rethink the way in which nature and culture, knowledge and politics are interrelated. ${ }^{4}$ In this sense, the discourse on the Anthropocene offers

\footnotetext{
${ }^{4}$ It is beyond the scope of this article to delve into the critique of the Anthropocene, either as a tool of universal history, which reduces humanity to a collective subject blindly seeking material progress, or as an imprecise meta-history which upholds the construction of teleological grand narratives with preordained aims. For more on this, cp. two special issues Telos 172 with an introduction by Timothy W. Luke, and Telos 177 with an introduction by Jon Wittrock and Richard Polt.
} 
heuristic devices that challenge the dominant logic of economic growth at virtually all costs. Moving away from an anthropocentric worldview might sound too utopian, but central to this debate is the call to move away from the utilitarian, profit-maximization driven logic of industrial civilization. This indicates a need to change both the mode of production and the way of life determined by capital accumulation.

These themes are also crucial to the discourse on eco-civilization construction, which therefore can be positioned within the broader conceptual framework of global prosperity [38].

Global prosperity is not merely based on economic indicators, but also on the possible achievement of socially sustainable prosperity. For a long time, the position of a country in relation to others has been based on the quantitative parameters of its Gross Domestic Product (GDP), creating a syllogism between the size of the country's economy and its global power. The GDP world's logic decided, as Leonardo Palumbo noted, 'which countries should lead the institutions of global governance' [44]. During the last few years, however, various scholars have started questioning the prescriptive power of the GDP logic as the key indicator of economic performance, and the axiomatic adoption of the GDP to assert the importance of a country in terms of global governance has been considered problematic [15]. One of the major criticisms of the GDP world's logic is the assumption that the exploitation of natural resources counts $100 \%$ as profit, without taking into consideration the significant costs of human and environmental degradation. The historical record of economies and their growth (or degrowth as the case might be) makes plain that 'crisis' is an attendant and inherent feature of this very human endeavour. Nonetheless, after each downturn, dominant thinking returns our collective efforts in pursuit of growth. This is not to argue that growth, per se, is evil but, rather, how it is understood and its meaning for individuals, societies and, indeed, civilization is problematic. It is thus important to take on the challenge and opportunity (as the Chinese compound word for 'crisis' -weiji-suggests) that this critical juncture in the post-GDP world affords us. This means we need to revisit and reconceptualize growth by shifting the focus of attention from a narrowly material and quantitative approach, which privileges the connection between size, speed and scale of economic growth, to an investigation of the quality of life, which could function as a heuristic device to rethink growth and human development. This leads to the realization of the necessity to explore an alternative vision and strategy for eco-socially sustainable global prosperity, which is radically different from an economistic idea of growth and entails a different pathway of global governance. This exploration requires an epistemological shift from a narrowly quantitative approach, based only on speed, size and scale of economic growth, to an interdisciplinary and transcultural framework, which should be focused on the possibility of improving the quality of life and human wellbeing. This means first of all that there is a need to adopt a multi-tiered approach that embraces the local, the national and global levels as a way to realize mindful, socially inclusive pathways to sustainable development. More specifically, it means we should both focus on the quality of life, exploring how we live, and also try a new course of assessment of how we are doing, with the objective of achieving the three goals of environmental sustainability, socially inclusive economic growth and poverty alleviation. The conundrum of finding new pathways to global prosperity, in the light of the increasing socio-economic inequality, has a lot to do with the fast pace of globalization, which seems to have accelerated the shift and spread of ecological crisis [27, 52]. 
Even in China, the GDP logic seems to be contested: President Xi Jinping has been famously quoted for emphasizing that 'We should no longer evaluate the performance of officials simply by GDP growth. Instead, we should look at welfare improvement, social development and environmental indicators to evaluate leaders' [62]. Since the beginning of the economic reforms in 1979, rapid industrialization, extensive land development and full-scale urbanization have been the priorities of the Chinese government's policies. For more than thirty years, the Chinese economy has registered growth at an annual average of $9.8 \%$ [41]. But in 2012, however, it became clear that China was 'a speeding train at a turning point' ([55]:3): after a prolonged period of high-speed economic growth, Chinese society was experiencing unprecedented ecological pressures and environmental constraints, due to the emergence of serious problems such as soot pollution, ozone depletion, fine particulate matters, and volatile organic compounds. Therefore, in the last few years, we have witnessed a growing emphasis on the importance of re-balancing the economy, promoting sustainable growth, and accepting the 'New Normal (xin changtai)': a vision of a qualitatively different developmental pattern within the context of a softer, and perhaps more sustainable, pace of growth [31].

The government's prime concern for the 12th Five Year Plan (2011-2015) [12th FYP] was centred on the question of re-balancing the economy, taking into consideration the significantly uneven distribution of the benefits of growth across society. The incipit of the text puts forward the self-aggrandising argument that: 'Tremendous achievements have been made in various aspects including the construction of a socialist economy, socialist politics, socialist culture, and ecological civilization.' It is clear, however, that much more needs to be done in relation to environmental protection in order to 'comprehensively build our capacity for sustainable development'[7]. The 12th FYP seems to reveal the intention of rebalancing the economy, responding to the need to spread the benefits more equally, reducing socio-economic inequality, as well as constructing a resource-conserving and environment-friendly society. The plan's targets aim at setting an energy consumption cap by 2015; a $16 \%$ energy saving in terms of intensity and a $17 \%$ carbon intensity reduction (per unit of GDP), an increase of the proportion of non-fossil fuels in primary energy consumption from $8.3 \%$ in 2010 to $11.4 \%$ in 2015 ; an increase in forest cover to $21.66 \%$ (Ibid). Li Junfeng, Deputy Director General of the Energy Research Institute in Beijing from 1999 to 2011, commented on the overall intention to seek 'inclusive growth', arguing that the plan's ambition 'to turn China into a model of low-carbon growth, was likely to have uneven results, due to differences in development' [18].

With the 13th Five-Year Plan (2016-2020) [13th FYP], launched in March 2016, China has set out a 'green is gold' top-level policy path with the declared aim of supporting the country's transition to an ecological civilization [54]. Premier Li Keqiang's speech accompanying the plan, which was hailed as the 'greenest Five Year Plan yet', emphasized the need to protect the environment while pursuing development [8]: Eco-civilization, epitomised as 'the management of the relationship between humans and nature in a comprehensive, scientific and systemic manner' ([54]:4) has become the fundamental tenet of green 
development with Chinese characteristics: this was presented both as the key national governance strategy and China's way of contributing to the 2030 Agenda of Sustainable Development Goals [SDG] [54].

With the 13th FYP's emphasis both on the structural reform of the energy system and the overall development mode, the Chinese leadership also indicated their view of the New Normal as encompassing a number of shifts in the dominant pattern of urbanisation, in order to achieve a smoother and more sustainable transition. The campaign to 'Advance Ecological Civilization and Build a Beautiful China' [64], could point in the direction of the necessity to move away from a dominant pattern (with the relevant metanarrative) of full-scale urbanisation, which has often prioritised the building of grandiose cities of spectacle as opposed to liveable cities where human beings want to live $[21,57]$. According to a study by the McKinsey Global Institute, rural to urban migration will create 400 million new urbanites by 2020. By 2030, one billion Chinese will be living in cities, with more than 221 Chinese cities having a population of over one million. For China's central planners, urbanisation is expected to be a key economic driver in the coming decades, with the overall urban composition of China's population expected to rise from $54 \%$ in 2014 to $70 \%$ by 2030 (as indicated by household registration or hukou) [61]. How China achieves such a rapid and large-scale change without locking in high-carbon patterns of growth is a crucial question for global sustainability and global prosperity [53]. The need for innovation at multiple levels in China [21] mirrors wider global-national-local challenges associated with the implementation of the SDG, including no. 11 - "Make cities and Human Settlements inclusive, safe, resilient and sustainable". Based on the connection between ecocivilization and eco-socialism [22, 23, 38], China's urban challenges are therefore social, as well as environmental, and intrinsically human. Beyond conglomerations of buildings, infrastructures and technologies, cities are also essentially human; singular sites of human aspiration as the unique mix of both 'home' and neighbourhood with anonymity and productive encounters with others. As the most sophisticated, historically durable and complex systems 'innovated' by humanity, as well as themselves primary sites and sources of social, technological, cultural and political forms of innovation, cities are key cradles of experiment in the construction of the new forms of complex system self-governance that must characterize low-carbon societies more broadly. This is extremely relevant to the discourse on eco-civilization China, as well as to the discourse on global prosperity [53]. The relevance of eco-civilization as a policy concept is linked to the growing awareness of the fact that improvements in environmental protection are essential to economic development. Examples of failed eco-cities, such as Dongtan outside Shanghai [10], and tragic disasters like the explosions at the hazardous-chemical storage facility on 12 August 2015 in the Dongjiang Free-Trade-Zone in the Tianjin Binhai new area $[16,24]$, where the company Ruihuan International Logistics was operating, demonstrate that neglecting this human dimension has a very high cost attached to it. This requires us to think seriously about the subjective realities of the populations that constitute urban systems, questioning the logic of economic growth at all costs, and going beyond the one-dimensional economic ideology of modernisation development [23]. It is important both to understand that the concept of eco-civilization did not originate in the political arena, but in the intellectual domain, and also to evaluate what is the relationship between the two fields. 


\section{The Origin of the Term Eco-Civilization: Ye Qianji's Work on Ecological Agriculture}

At the Government level, the concept of eco-civilization became prominent in 2007 , especially following the Report to the 17th National Party Congress (NPC, 15-21 October 2007), which was delivered by former President Hu Jintao, but prepared by Premier Wen Jiabao [19]. Significantly, in the 2007 Report the term 'eco-civilization' does not appear per se, but it is significant that the environmental conditions are strictly connected with the necessity to 'pursue comprehensive, balanced and sustainable development' (Ibid). The emphasis is on the adoption of 'an enlightened approach to development that results in expanded production, a better life and sound ecological and environmental conditions' (Ibid), while the goal is to create 'a resource-conserving and environment-friendly society that coordinates growth rate with the economic structure, quality and efficiency, and harmonizes economic growth with the population, resources and the environment, so that our people will live and work under sound ecological and environmental conditions and our economy and society will develop in a sustainable way' (Ibid). In the Report, the word 'ecology' (shengtai) is associated with 'conservation', and the priority is identified as the enhancement of China's capacity for sustainable development through an improved conservation of energy and resources. Even though the Report seems to indicate a different mode of 'development', rethinking the structure of industries, patterns of growth, and modes of consumption in relation to energy resources, the fundamental limitation of this focus lies in a certain vagueness, determined by the lack of definition of 'sustainable development' in relation to the historical contingency of China in 2007. The idea of 'sustainable development' in China is influenced both by endogenous (i.e. the priorities of national development) and exogenous (i.e. the international debate on 'sustainability') factors. The use of this term in 2007 seems to echo the 1987 Brundtland Report $^{5}$ and its original definition of sustainable development: 'Development that meets the needs of the present without compromising the ability of future generations to meet their own needs' ([5]:43). However, this did not include any reference to 'maintaining human wellbeing, social equity and environmental quality' over an extended period of time ([28]: xiv), which would have indicated an alignment of the ideals of eco-civilization with social justice.

With regard to eco-civilization, the mouthpiece of the CCP, The China Daily, expands on it by arguing that:

It is not a term the Party has coined just to fill a theoretical vacancy in its socialism with Chinese characteristics, but rather a future-oriented guiding principle based on the perception of the extremely high price we have paid for our economic miracle. This concept reflects an important change in the Party's understanding of development. Rather than emphasizing economic construction as the core of development as it did in the past, the Party authorities have come to realize that development, if sustainable, must entail a list of elements including the right relationship between man and nature [11].

\footnotetext{
${ }^{5}$ The Report, named after Gro Harlem Brundtland - the Chairperson of the United Nations World Commission on Environment and Development (WCED) - is also known as 'Our Common Future'. The Commission was created by the United Nations in 1983 in light of the progressive deterioration of the human environment and natural resources. The Brundtland Report, published in 1987, coined and defined the term 'sustainable development'.
} 
It is important to remember that the discussion on eco-civilization had already started in Chinese academic literature twenty-five years earlier, thanks to the contribution of the agricultural economist Ye Qianji (1909-2017). Ye was the first to use this concept and to emphasise its importance for the practice of sustainable agriculture in China. More specifically, he advocated the application of 'ecological agriculture' in the experimental areas of Beibei District and Dazu County in Chongqing. In 1982 he published his dissertation Shengtai nongye-Woguo nongyede yici lüse geming (Ecological Agriculture - A Green Revolution in my Country's Agriculture) [67]. His theory about ecologically sustainable agriculture and its merits was later expanded into a book, which emphasized the contribution of eco-agriculture to the future sustainable development of the country [68].

It appears that the term eco-civilization' is derived from 'ecological culture' (экологическая культура), a term which first appeared in the former Soviet Union in Scientific Communism in 1984 ([33]:43). An abridged version was translated in the Guangming Ribao, but the word 'culture' was replaced with 'civilization', in Chinese shèngtài wénmíng, or eco-civilization [71]. It is interesting to note the parallelism with the origin of the term Anthropocene, which had already appeared in 1960-61 in the Reports of the USSR Academy of Sciences [9] to refer to the late Quaternary era, while in the West, until the intervention of Crutzen and Stoermer in 2000, this was simply labelled as the Holocene.

In June 1987 (i.e., twenty years before Hu Jintao's Report to the 17th NPC), in his opening speech at the National Conference on Eco-agriculture, Ye Qianji emphasized that China's ecological environment was progressively deteriorating, and therefore he launched his call to arms, 'vigorously promoting the construction of eco-civilization' at the national level. He clarified that eco-civilization means that 'humanity can both benefit from nature, and also act in the interest of nature: while humanity has a transforming effect on nature, humanity also has to protect nature, since this is the only way for man and nature to maintain a harmonious and unified relationship' (quoted in [34]:520; Cp. also: [35]). According to Ye, the twenty-first century should be 'The Century of Ecological Civilization Construction' [68]. This indicates a radically different ethical foundation of eco-civilization when compared with industrial civilization: respect for nature to realize ecological justice as opposed to utilitarian, profit-driven and technology-innovation oriented functionalism. The emphasis on protecting nature could be linked to the idea of protecting both ecological and social justice. In this sense, eco-civilization construction points towards the relevance of setting climate sustainability goals and gives much more depth to the concept of 'sustainable development'.

Ye also had some significant insights into global environmental issues, useful for global governance and social prosperity. In December 1999, when he was already 90 years old, Ye presented his 'ecological catastrophe theory' at the Beijing Xiangshan Scientific Conference. He argued that, from the perspective of modern ecological economics, the current global environmental system was in a state of 'ecological catastrophe'. He spoke of 'environmental damage and turmoil' and offered the following five points as evidence: 1) the Earth's environmental system has evolved from a natural ecological cycle to an essentially human ecosystem. As a result, the ecological security of the global environmental does not function anymore; 2) human behaviour and activities have affected the changing level of natural ecology, to the extent that the 
real meaning of 'fluctuation', 'turbulence', or 'threat' is an alarming quantitative and qualitative change, which is leading to the disastrous collapse of nature; 3) the main human ecological cycle of human destruction of the Earth's environment is a reverse succession process, moving from natural forests, through agricultural land or farmland, to desertification and ultimately no man's land, also known as the death zone; 4) ecology is the science of survival, therefore the anthropogenic ecology cycle should also examine the survival of life in the living space, whose status is characterised by a series of levels, from green (indicating an excellent level of life) through grey (survival state), to white (subordinate survival), yellow (extremely difficult to survive), red (alert borders), and then black (non-ecological); 5) in the twenty-first century, we should update the ecological system's structure and strengthen ecological functionality in order to maintain peace, stability and order, while building an ecological socio-economic habitat. This is what Ye calls 'the harmonious development of eco-civilization', which for him is 'the mission of our times', and could also be considered as a precondition for socio-ecological sustainable prosperity, based on harmony and inclusiveness between man and nature, and between individuals and society. Ye recognises that human activities are limited, and due to the serious extent of the damage caused to the natural and ecological system, governments need to find adequate tools of governance to guarantee a form of human development based on a healthy and dignified way of living [69].

After Crutzen and Stoermer proposed the theory of the Anthropocene in 2000, this was received with interest in the Chinese academic circles. The equivalent term coined in Chinese was renleiji. Particularly significant for Chinese intellectuals at the dawn of the new century was the idea that the beginning of this new geological era coincided with the new period of civilizational development which had started with the Industrial Revolution, when human activity progressively became the dominant force in influencing and changing the Earth system. At the turn of the century, the particular juncture for China's historical and socio-economic development, which was characterized by accelerated industrialization, extensive land development and full-scale urbanization, with all the relevant environmental costs, the resonance between the theory of Anthropocene and Ye's call to arms to promote eco-agriculture and eco-civilization as green revolution was immediately noticed: a vision of a perfectible future to counteract the unsustainable present [34, 35, 69].

Ye had already secured the scholarly community's acknowledgement of the fact that the development of the Earth's system was facing multiple ecological risks and challenges, and that these were influenced, or better determined, by human actions. Engaging with this debate, Ye summarized the four major issues at stake as follows:

First: global warming, the shortage of water and land resources, increasing dust storms, desert expansion, rising sea levels, frequent floods and other ecological disasters, had all resulted in unprecedented damage to the environment, as well as the loss of human life and assets. Second: the high-speed consumption of the Earth's resources is leading to a serious ecological deficit in the Earth's ecosystem. Third: species are dying, and their diversity has been severely damaged. Fourth: demographic expansion, an aging population, and gender imbalance all demonstrate that 'the faster the population expansion, the scarcer will be land and water resources' (Ye 2004). Ye defined this dilemma as an 'ecological economic paradox', which determined more acute, complex, and difficult to escape ecological risks. In his work, Ye raised the crucial question: 
"Rendingshengtian" haishi "Tianrenheyi"? [69], which can be literally translated as: “"Man's will, no heaven, decides' or 'Man lives in harmony with heaven'?” In both cases, 'heaven' could also be translated as 'nature': 'Man, by his efforts and determination, can conquer nature' or 'Man and nature are one'? Ye argued in favour of the second. By doing so, he substantiated and actualized the traditional philosophical concept 'Tianrenheyi', which was both the autochthonous prototype of environmental consciousness as expounded in the work of Lao $\mathrm{Zi}$ and Mencius ([72]:6), and also the foundation of the familiar model and, by extension, of the socio-political order in ancient China, ([42]:281).

Ye strongly believed that a correct understanding of the relationship between human beings and nature could have led to more balanced and sustainable socio-economic development: therefore, he advocated the reconstruction of the social blueprint based on a comprehensively new culture, which emphasized the need to treat nature like ourselves, respecting the laws of nature, and aiming at harmony with nature. He vehemently insisted that even if one can argue that man is the subject of nature, this does not mean that he is master of nature; if nature is the object for mankind, this does not mean that nature can be subjugated to the indiscriminate power of mankind. For Ye, 'humanity originates from nature, lives, multiplies and prospers in the natural environment, and therefore it should be in harmony with nature so that their coexistence can lead to common prosperity' (Ye 2004). Based on this recognition of the importance of a balanced (instead of distorted) relationship between man and nature, Ye analysed the struggle of our ancestors in the evolution of the original earth system: in order to guarantee their survival, and fighting against the adversities they experienced a progression of 'succession - differentiation - extinction - mutation - evolution'. Considering this long process, he defined the new law of ecological economy as follows: the extinction of ancient life, the law of rejuvenation, the emergence of biological advantages based on the law of domination and decline, the law of formation of life symbiosis; the four aspects of the law of chain evolution based on the struggle for survival (Ye 2004). From a historical perspective, Ye linked the past-present and future, emphasizing that we should learn from the path of ancient history, deriving inspiration, and reversing the logic of the Anthropocene in order to deal more wisely with the various crises in the new era, looking for strategic measures to deal with them and address them, since we are already witnessing how the continuous human violation of nature has triggered the perverse destruction cycle of ecological catastrophe, which has led to the retaliation of the natural laws against mankind.

\section{The Term Eco-Civilization in the Political Domain}

The academic and intellectual debate continued $[17,66]$ and Ye's original ideas were further developed, especially by Wen Tiejun as an advocate of the New Rural Reconstruction movement's aim to rebuild a positive social and economic structure to promote rural sustainability $[58,59]$.

As previously mentioned, it was only in 2007 that the term 'eco-civilization' entered the political domain. However, the milestone in the transition from the academic to the political realm was Hu Jintao's final Report at the 18th NPC, delivered on 8 November 2012, where Ecological Civilization appeared as the title of a new section (section 8) in 
the Report, and the term 'eco-civilization' was repeated 16 times [20]. This symbolized not only the passing of the baton of Presidential power from Hu Jintao to Xi Jinping, but also the embodiment of Hu's legacy. Hu was leaving in the hands of his heir a major unaccomplished task: the title of section VIII of his speech is emblematic, Making Great Efforts to Advance Ecological Civilization, and this follows section VII. Strengthening Social Development by Improving the People's Wellbeing and Making Innovations in Management. The idea of eco-civilization construction was enshrined in the Constitution, with a typical example of the future perfect tense: projecting the construction of eco-civilization in a possible perfectible future. Judging from the way in which Xi Jinping reiterated the importance of 'eco-civilization reforms' at the Third Plenary Session of the 18th Central Committee in 2013, President Xi acknowledged the necessity to reconcile the contradictions between economic growth and environmental decay: 'To protect the ecological environment is to protect productive forces. To improve the ecological environment is to develop productive forces. A good ecological environment is the most just public product, one that most fully promotes the wellbeing of all the people' [63]. The similarity of the political language is remarkable.

$\mathrm{Hu}$ Jintao formulated the idea of eco-civilization, upholding the claim that shengtai wenming was strictly connected with 'Beautiful China' and sustainable development: 'Faced with increasing resource constraints, severe environmental pollution and a deteriorating ecosystem, we must raise our ecological awareness of the need to respect, accommodate and protect nature. We must give high priority to making ecological progress and incorporate it into all aspects and the whole process of advancing economic, political, cultural, and social progress, and we must work hard to build a beautiful China and achieve the longlasting sustainable development of the Chinese nation' ([20] Italics added). At the end of section VIII of his speech, Hu Jintao seemed to connect national and global ecological security with governance, stating: 'We must treasure nature more consciously, protect the ecosystem more actively, and strive to usher in a new era of socialist ecological progress.' [20].

Here, I am using the English translation of the text. It is significant that $\mathrm{Hu}$ Jintao indicates shengtai wenming as an indispensable element for the advancement of economic, political, and cultural and social progress, framing it as a sort of holistic and intertwined mechanistic model. However, I find both interesting and problematic the fact that shengtai wenming is translated into English as 'ecological progress'. This happens again in the English translation of Xi Jinping's book The Governance of China, ([64]:11-12, 107, 113, 230-234, 230, 477). The idea of 'civilization' (wenming) in China is extremely complex: when we analyse it from a historical perspective, its connotation goes all the way back to Sima Qian's Shiji (Historical Records) [50], and harks back to the whole idea of a self-conscious assertion of the Han civilization [29]. When the official political discourse took over the idea of shengtai wenming from the academic sphere, the idea of ecological civilization became part of a teleological discourse, characterised by a normative, prescriptive and also deterministic connotation of progress, projected into the future perfect. In Hu Jintao's [20] Report, the discourse of shengtai wenming is strictly interconnected with the whole idea of promoting the master narrative of China's Story of Progress. This is why it is important to analyse the temporalities of the idea of ecological civilization (or 'progress') in the political discourse, moving between the past, present and future. In the official political documents, the concept is formulated in such a way, which demonstrates how it is built on 
the past but its anticipated achievement is projected into the future. The idea of civilization was appropriated by the CPC after the foundation of the 'New China': during the Maoist era it was articulated with an emphasis on the importance of raising human quality levels, with particular attention being paid to material civilization. Then, during Deng Xiaoping's 'new socialist period', it expanded to include the socialist spiritual civilization. With Jiang Zemin, we notice a stronger focus on political civilization, and more recently, under Hu Jintao's aegis, ecological civilization has become the new addition to the Chinese civilization discourse. As much as this campaign to civilise citizens can be seen as part of a project of 'pan-politicisation' ([32]:100), with a strong ideological connotation linked to this continuum, every step is also indicative of each leader's legacy of leaving an unaccomplished task for his heir to consider. Material, spiritual, political and ecological civilization can all be seen as part of the country's and the nation's overall development pathway and, as I will explain later, the 'civilization project' was to come full circle with Xi Jinping's China Dream [64]. The fact that the CPC discourse on civilization has embraced the idea of 'eco-civilization', appropriating it from academic discourse, could be interpreted as an attempt to counteract the growing and widespread criticism of environmental degradation, which might put into question the success story that is China's economic miracle.

When $\mathrm{Hu}$ Jintao first mentioned shengtai wenming, in the 2012 Report, he associated it with the steady and rapid 'development' of the economy: after a long list of major material achievements he argued that 'Solid steps have been taken to promote ecological progress, and comprehensive progress has been made in resource conservation and environmental protection' ([20], Italics added). Hu Jintao also boasted about the CPC's accomplishments, claiming that through 'over 90 years of hard struggle' the Party had succeeded in 'turning the poor, backwards, old China into an increasingly prosperous, powerful, new China' (Ibid.). The second time $\mathrm{Hu}$ mentioned shengtai wenming, however, he changed the tone and indicated that 'ecological progress' was something to be achieved under conditions that are not so advantageous since 'unbalanced, uncoordinated, and unsustainable development remains a big problem' (Ibid. Italics added). There is an evident contradiction here since the contrast between these two sets of adjectives could not be more acute, especially due to the proximity of these sentences in the text and also on comparing the negative assessment with the declared aim set in the 2007 Report 'to pursue comprehensive, balanced and sustainable development' [19]. Resources' conservation and environment-friendly society were both two key tenets of the Hu Jintao's 2007 Report and fundamental elements of the 12th FYP (2011-15). They are known as the pillars of the 'two oriented society' (liangxing shehui), and inscribed in Hu Jintao's idea of the 'scientific outlook on development' (kexue fazhanguan), which was meant 'to take people as the main thing [yiren weiben]' [14]. In Hu Jintao's words: 'We must fully implement the overall plan for promoting economic, political, cultural, social, and ecological progress, ${ }^{6}$ ensure coordinated progress in all areas of endeavors in the modernization drive, balance the relations of production with the productive forces as well as the superstructure with the economic base, and continue to expand the path of development that leads to increased production, prosperity, and a good ecosystem (...) We have called for building a harmonious socialist society and speeding up ecological progress, and we have adopted

\footnotetext{
${ }^{6}$ This is known as the 'five in one' (wuwei yiti).
} 
overall implementing steps for advancing the cause of socialism with Chinese characteristics' ([20] Italics added). The concept of shengtai wenming is connected to another key element of the Party's rhetoric (i.e., harmonious society), and it becomes progressively construed as a socialist goal to be achieved in the future, in what Hu Jintao defines as 'the new stage in the new century' since 'Promoting ecological progress is a long-term task of vital importance to the people's wellbeing and China's future' [20].

$\mathrm{Hu}$ Jintao acknowledges the necessity for the Party to 'put people first and to pursue comprehensive, balanced and sustainable development'. He argues that the Party's strength, the nation's future, and the people's wellbeing go hand in hand: 'We have strived to ensure and improve the people's wellbeing, promoted social fairness and justice, worked to build a harmonious world, and strengthened the Party's governance capacity and advanced nature' ([20]. Italics added).

This reveals, once again, an attempt to connect eco-civilization with the conservation of resources, but the aim is also to create a better living environment for the people. In addition to information presented in the 2007 Report, here one can also detect the seeds of a political discourse, one that raises questions about the overall mode of production, which, after five years, had proven to be even more unbalanced and unsustainable, demonstrating a more mature concept of sustainable development, on paper at least, which is connected with social justice ([28]:xiv).

\section{Xi Jinping: Eco-Civilization, Beautiful China and the China Dream of Prosperity}

The complexities of the 18th Party Congress set the tone for positioning the discourse on eco-civilization, understanding not only its rationale and its aims but also its main challenges.

With the transition from $\mathrm{Hu}$ Jintao to Xi Jinping, the metanarrative of the China Dream (Zhongguomeng) of national rejuvenation, greatness and prosperity, and military strength, which is strictly connected with China's global ascendance, began to incorporate the discourse of eco-civilization [30]. The key event was the Third Plenum of the CPC's 18th Congress (9-12 November 2013), when President Xi unveiled the ambitious plan of 'comprehensively deepening the economic reforms' through a rethinking of the process of resource allocation [37]. While during $\mathrm{Hu}$ Jintao's era the emphasis was more on the idea of the construction (jianshe) of an ecological civilization, with Xi Jinping the emphasis shifted to the advancement (tuijin) of the ecological civilization, with a stronger sense of urgency both for the nation and 'the interests of the citizens' ([30]:110). It is significant how this advancement is discursively constructed within the emerging and interconnected discourse of 'building a Beautiful China (jianshe meili Zhongguo)'. In Xi's words: 'Ushering in a new era of ecological progress and building a beautiful China is an important element of the China Dream' ([64]:233. Italics added). Under Xi Jinping, 'Advance Ecological Civilization and Build a Beautiful China' became a mantra. However, as previously mentioned, the shift in terminology does not necessarily coincide with substantial achievements on the environmental protection front ([64]:229-234). The progressive expansion of the rhetoric trope of meili Zhongguo美丽中国 during the first term of Xi Jinping's Presidency can be interpreted as a partial antidote to the social and environmental challenges 
facing China's political and socio-economic development, due to the unprecedented ecological pressures and environmental constraints ([64]:234).

Beautiful China is listed in an article published on 14th November 2016 by the Renmin Ribao as one of the 25 most used key phrases of Xi Jinping. After acknowledging that 'The 18th National Congress of the CPC emphasized building a Beautiful China for the first time and put the construction of eco-civilization in a prominent position', Beautiful China is then defined as: 'the sum of the beauty of the environment, the beauty of the times, the beauty of life, the beauty of society and the beauty of the common people' [49].

In the 2014 book The China Dream, distributed in English Translation by Chinese Embassies around the world, the second and longest section of Chapter II, entitled 'Chasing Dreams' (following the first short one entitled 'Seeking Dreams', which relates to the past), is dedicated to eco-civilization. Interestingly, in this English version of the book, wenming is translated as 'civilization'. In this section, the emphasis on the connection between China Dream, Eco-civilization and Beautiful China is clear, and eco-civilization is hailed since: 'In the face of the grim situation, including tight resource constraints, serious environmental pollution and ecosystem degradation (...) China strives to build a Beautiful China, effectively safeguarding the environmental rights and the interests of the citizens' ([30]:110).

$\mathrm{Xi}$ Jinping reiterated that the advancement of ecological civilization is one of the five national goals 'in building a moderately prosperous society in an all-round way', namely: economic modernization, socialist democracy, social development, cultural development and eco-civilization (Ibid.). The 'Five-in-One' model - which is another of Xi Jinping's top 25 key phrases [49] - claims to integrate not only the economic, social and ecological but also the political and cultural dimensions of development; it is important to note that 'The latter two focus on changes in the behaviour of public officials and ordinary citizens, respectively' ([54]:2) and therefore they could be read as part of the campaign to civilise citizens, as well as the anti-corruption campaign. In 2012, Xi Jinping argued that eco-civilization construction, from the point of view of temporalities, 'is a cause that benefits both contemporary and future generations' since it is 'vital to the future of human beings' ([30]:110). Xi also acknowledged that 'The public is greatly concerned about the environment' ([64]:232), and insisted on outlining the Government's responsibility: 'We must take a responsible attitude towards our people and future generations, be resolute in controlling environmental pollution, strive to usher in a new era of ecological progress and improve the environment for our people to live and work in' ([64]:230. Italics added). This would seem to indicate that eco-civilization is both a governance and prosperity issue, both at the national and the global level: 'Protecting the environment, addressing climate change and securing energy and resources is a common challenge for the whole world' ([64], 234). However, both in Hu Jintao and Xi Jinping's speeches one can also see a declared attempt to expand the social and political agenda in the name of creating a 'harmonious society' and realising the 'China Dream'. But this could also be interpreted as a skilful and tactical rhetoric device, which allows the Party to present the public with a series of populist welfare goals, while in reality enabling the Party to discursively continue to manoeuvre public support. The future perfect tense still dominates Xi Jinping's political discourse, with an evident indication of the projection of ecological transformation into the future: 'China will respect and protect nature, and will accommodate itself to 
nature's needs. It will remain committed to the basic state policy of conserving resources and protecting the environment. It will promote green, circular and lowcarbon development, and will promote ecological progress in every aspect of its effort to achieve economic, political, cultural and social progress... and will leave our future generations a working and living environment of blue skies, green fields and clean water' ([64]:233-234. Italics added). Some of these statements seem to echo Ye Qianji's original call for 'the harmonious development of eco-civilization', as well as the most recent debate in the academic arena.

In Xi Jinping's speeches, the construction of 'eco-civilization' seems to assume more and more the characteristics of a variation on the theme of 'sustainable' development, increasingly interwoven into state power rationality [64]. As Chinese political rhetoric embodies the tropes that seem to encourage the population to transform their lifestyles and adopt greener and more civilised practices, the forward- and progressive-looking mantras on the environment contribute to creating a new discursive platform by which to assess performances at the local level while asserting the legitimacy of the state. The somewhat vague notion of green growth, implicit in the idea of eco-civilization, assumes its full relevance in the link between state building and nature-peoplemaking so that the environmental realities are truly real only in relation to the state objectives and its master narrative of a magnificent and progressive future.

\section{The Renaissance of the Intellectual Debate on Eco-Civilization}

In the last few years, the intellectual debate on eco-civilization has re-ignited.

One of the most thought-provoking positions is offered by Pan Jiahua, Director of the Institute for Urban and Environmental Studies at the Chinese Academy of Social Sciences. His research explores the practices of environmental knowledge production operating through state-projects of eco-development and contributes to a better understanding of China's positionality in terms of global governance. First, Pan invites us to go beyond a somewhat narrow interpretation of 'eco-civilization', which views it as a set of moral and ethical behavioural norms aimed at achieving harmony between man and nature. He argues that eco-civilization affects the whole life of mankind on this planet since the foundation principles of eco-civilization are respect for nature and social justice [48]. For Pan, these are the fundamental social values which should inform political economy in such a way that the production model would be characterised by low input, circularity and efficiency, while the consumption mechanisms would follow green, resource-saving and healthy lifestyles. Thus, ecocivilization construction could help to ease the increasingly intense conflicts between human beings and the environment, since it promotes the prioritization of a social form of civilization, under which people, society and nature are inclusive, harmonious, and sustainable [45].

Pan also emphasizes the necessary connection between the ideal of building a Beautiful China and an awareness of the limitations of the ecosystem's capacity in relation to the scale of the country's socio-economic activities: 'The earth's resources and environmental capacity are limited; that is to say, ecological supply is fixed' ([45]:154). At first, this statement seems to contradict the former premise since it appears to derive from an economic concern focused on the quantitative assessment 
of the supply-demand ratio of the ecosystem - 'If demand exceeds supply, the ecosystem will inevitably be degraded, as will be the beauty of nature' (Ibid.) -, and more broadly the balance or imbalance between demographic growth and the availability of resources. However, Pan's analysis goes beyond the quantitative mechanics of market indicators and econometrics. Pan is deeply interested in connecting the economic rationale with a call for institutional change, which involves a call for critical ways of rethinking the governance structure in relation to the choice of development pathways. Pan relates his reasoning on the pressing nature of the environmental challenges, such as ecological degradation, climate extremes, energy security and resource capacity, to the potential for setting and implementing climate SDGs. In his analysis of the challenges to liveability and sustainability ([53]:33-57), Pan echoes the concerns publicly expressed in Hu Jintao's [20] speech with regard to the 'unbalanced, uncoordinated and unsustainable development' of China [20]. Of all the challenges to sustainable development, Pan is particularly interested in the connection existing between the social (e.g. inequality, poverty), economic (e.g. the economic/financial crisis), environmental historical contingencies (e.g. pollution, the depletion of natural resources, ecological degradation, and climate change) and the institutional framework and pathways to development [48]. Ultimately, Pan proposes a more holistic approach, which starts with an acknowledgement of the environment as a whole being an economic, biological and human resource.

The pars construens of Pan's discourse is his determination to find a solution. Pan argues that rethinking the economics and politics of development necessarily requires nothing less than a paradigm shift. Therefore, he emphasizes the need to move away from the logic of the industrial civilization, which is based on utilitarian ethical principles, aims at the maximization of profit, and ultimately places its priority on the accumulation of capital for the few, while directing much less care, or no care at all, towards people and nature. He proposes a shift of civilizational views: from industrial to ecological in order to promote 'ecological prosperity (shengtai fanrong)', which for him is 'not a simple form of material prosperity, but a kind of prosperity based on the harmony-unity-integration between man and nature' ([47]:215). Here, he uses the traditional philosophical concept 'Tianrenheyi', further developing Ye Qianji's original idea.

Pan's elaboration on eco-civilization can be linked to the discourse on the Anthropocene since the original coinage of the concept of this 'new geological era', entirely dominated by human activity over nature, was linked to the industrial revolution [13]. The idea of eco-civilization is also based on a reconsideration of the unsustainable development model that has arisen out of industrial civilization, whose teleology was based on the assumption that industrialization was the key marker of progress, and therefore civilization. Pan Jiahua raises the rhetorical question of whether there is room for China to pursue industrial civilization any further ([48]:43). His answer, based on his in-depth study of the rate and scale of urbanisation in relation to industrialization in the automobile sector, is negative. One of the major problems with the rapid growth of the Chinese economy is the consumption of primary energy resources, which are required to support industrialization. Pan concludes that the paradigm shift from industrial civilization to eco-civilization is even more urgent for China than the rest of the world, but he also acknowledges that it is indeed a global challenge since it requires drastic changes to global institutions: under the pressing global trend of urbanisation, industrialization has very limited space, social inequality is 
growing (e.g. income disparity, regional disparity, rural-urban disparity), and we all witness a continued, large scale demand for exhaustible resources. This leads, inevitably, to ecological degradation, environmental pollution (water, air, municipal solid waste, etc.), climate change (GHG emissions), and increasing global imbalances. The growing awareness requires governments to work together in order to accelerate the shift to eco-civilization. In Pan's opinion, the more advanced nations must take the lead in promoting the transition since they are the ones with the necessary resources (both economic and human).

\section{Conclusions}

A 'Beautiful China' will not be achieved by building upon, harnessing or excavating every last inch of natural territory, but by sparing some of nature's bounty - some for other creatures that walk the earth, and some for posterity - to share and enjoy [46].

Any harm we inflict on nature will eventually return to haunt us. (...) Taking a driving seat in international cooperation to respond to climate change, China has become an important participant, contributor, and torchbearer in the global endeavour for ecological civilization [65]. ${ }^{7}$

This article has examined both the political discourse and the intellectual debate on ecocivilization in China. It began by deconstructing and reconfiguring the concept of 'locality' in order to underline the importance of examining China not as a monolithic entity, but by taking into consideration the country's self-positionality as a place of knowledge production. Building both on Agnew's remarks about China's 'timespace crisis' and Barmé's emphasis on the intrinsic risks of blindly accepting the linear, rational and almost mechanically instantiated teleology of 'The China Story', the article has concentrated on what I would argue is a temporal disconnection in the Chinese political discourse on eco-civilization. I have defined this feature as 'future perfect tense' since the political documents seem to contain a recurring projection of the solution into an allegedly perfect future. In reality, the debate on eco-civilization started in the 1980s in the academic domain and was later appropriated by the political discourse. To understand the changing relationship between economic growth and human development in China, as well as its potential impact on global governance and eco-socially sustainable prosperity, it was, therefore, necessary to analyse both the political discourse and the intellectual debate, evaluating what are the possible elements of convergence or divergence. Delving into the intellectual debate, this article has proved that the concept of eco-civilization, in a similar way to the Anthropocene concept, has a significant discursive power: it allows for a paradigmatic shift from the binary political economy discourses of 'growth' versus 'development', and 'socialism' versus 'capitalism', to the inquiry of new pathways to eco-socially sustainable prosperity.

\footnotetext{
${ }^{7}$ Xi's allusion to China playing a major role on climate change could be read as a demonstration of international power in light of the United States' ambivalence towards the Paris Agreement, but this is beyond the scope of this article.
} 
As Ye Qianji originally indicated, and Pan Jiahua later elaborated, the real challenge for China is how to de-couple economic growth from environmental degradation. They both offered significant insights, especially in terms of the necessity: 1.) to go beyond the logic of industrial civilization, and 2.) to rethink China's development matrix and measurements of economic achievements in a way which abandons the mere GDP logic and proves more environmentally conscious of the quality of life and social wellbeing. Therefore, the concept of eco-civilization can be used as a heuristic device, one which challenges the dominant logic of economic growth at all costs, and can help, at least partially, in a rethinking of the issues linked to growth and human development. In this sense, the call for eco-civilization is much more than a version of the Anthropocene 'with Chinese characteristics': this concept could possibly offer situated understandings of the political and socio-economic system in relation to alternative ways of exploring eco-social prosperity in China as a locality.

The risk remains, however, that eco-civilization might just be incorporated into 'The China Story' and merely used as a piece of that teleology, a tactical political rhetoric device allowing the Party to present the public with a series of populist welfare goals, and enabling it to discursively continue to manoeuvre public support to prove its selffulfilling prophecy. The future perfect tense predominant in the political discourse on eco-civilization could anesthetize listeners, potentially convincing them that the ecobiopolitical discourse will automatically find its own solution in reality, thanks to the driving force of repetition and slogan-like techniques. Projected into the future, the discourse of eco-civilization would then avoid addressing the current 'timespace crisis': it would create a temporal-spatial dystopic configuration that would operate like an auto-immune system; a fantasy of total protection and bio-political securitization, which in reality conceals the real danger, which is in the present.

On the contrary, the convergence of the academic discussion on eco-civilization with the politics-policy nexus (the connection of political goals with policy tools) could provide an opportunity to question (if not openly disrupt) the unsustainable logic that rapid industrialization, extensive land development and full-scale urbanisation leads to long-lasting progress. While the official discourse on ecological civilization in China plays the role of metanarrative, and it could be interpreted as the government's response to environmental degradation and the multiple protests that have been witnessed in many cities in China over recent years, it is the academic realm, which is exactly where the debate on eco-civilization began, that has so far offered more significant insights on how to address the challenges of both the present and the future.

In the Chinese context, however, the academic discussion might help to highlight alternative developmental pathways, but changes can only happen with the state's intervention. The question today, especially in light of Xi Jinping's emphasis on 'eco-civilization' in his opening speech at the 2017 National Party Congress, ${ }^{8}$ is whether or not his poignant remark 'Any harm we inflict on nature will eventually return to haunt us' [65] stems from a deep awareness and a willingness to act, which could guide the leadership to prioritize the need for harmony between humans and nature and implement relevant policies in the 'new era' of the present that, according to Xi, sees China 'moving closer to centre stage and making greater contributions to mankind' (Ibid.).

\footnotetext{
${ }^{8}$ This article was completed in July 2017. It was only during the final revision stage in Sept.-October 2017 that I briefly had access to preliminary information on the 2017 National Party Congress.
} 
Acknowledgements This article has benefited from insightful suggestions from two anonymous peer reviewers, as well as the thought-provoking comments offered by my co-editor Ondřej Klimeš, to whom I am very grateful.

Open Access This article is distributed under the terms of the Creative Commons Attribution 4.0 International License (http://creativecommons.org/licenses/by/4.0/), which permits unrestricted use, distribution, and reproduction in any medium, provided you give appropriate credit to the original author(s) and the source, provide a link to the Creative Commons license, and indicate if changes were made.

\section{References}

1. Agnew, J. 2012. Looking back to look forward: Chinese geopolitical narratives and China's past. Eurasian Geography and Economics 53 (3): 301-314.

2. Agnew, J., and D.N. Livingstone, eds. 2011. Sage handbook of geographical knowledge. London: Sage.

3. Barmé, G., ed. 2013. Introduction. In China Story yearbook 2012. Red rising, red eclipse. Canberra: Australian Centre on China in the World.

4. Biermann, F., et al. 2010. Navigating the Anthropocene: The earth system governance project strategy paper. Current Opinion in Environmental Sustainability 2: 202-208.

5. Brundtland, G.H., ed. 1987. Report of the world commission on environment and development: Our common future. Oxford: OUP.

6. Cao, Q., H. Tian, and P. Chilton, eds. 2014. Discourse, politics and media in contemporary China. Amsterdam: John Benjamins.

7. CCCPC (Central Committee of the Communist Party of China). 2011. The 12th five-year Plan (20112015). http://www.china.org.cn/china/NPC_CPPCC_2011/2011-03/15/content_22143099_2.htm.

8. CCCPC (Central Committee of the Communist Party of China). 2016. The 13th five-year Plan. http://en. ndrc.gov.cn/newsrelease/201612/P020161207645765233498.pdf.

9. СССР Доклады Академии Наук (Reports of the USSR Academy of Sciences). 1960. Vols. 132-35 and 1961. Vols. 133-35. Leningrad: Izd-vo Akademii nauk SSSR, 1933-1992.

10. Chang, I.-C.C., and E. Stoppard. 2013. China's eco-cities as variegated urban sustainability: Dongtan eco-city and Chongming eco-island. Journal of Urban Technology 20 (1): 57-75.

11. China Daily. 2007. Ecological civilization (Commentary). The China Daily, 10. http://www.chinadaily. com.cn/opinion/2007-10/24/content 6201964.htm. 24 Oct.

12. Crutzen, P., and C. Schwägerl. 2011. Living in the Anthropocene: Towards a new global ethos. Yale Environment. http://e360.yale.edu/features/living_in_the_anthropocene_toward_a_new_global_ethos

13. Crutzen, P.J., and E.F. Stoermer. 2000. The "Anthropocene". Global Change Newsletter 41: 17-18.

14. Fewsmith, J. 2004. Promoting the scientific development concept. China Leadership Monitor 11 http://www.hoover.org/sites/default/files/uploads/documents/clm11_jf.pdf.

15. Fioramonti, L. 2017. The World after GDP: Politics, business and society in the post growth era. Cambridge: Polity Press.

16. Fu, G., J. Wang, and M. Yan. 2016. Anatomy of Tianjin port fire and explosion: Process and causes. Process Safety Progress 35 (3): 216-220.

17. He, A. (ed.). 2012. Dangdai Zhongguo Shengtai Wenming zhilu (Contemporary China's road to ecocivilization). Beijing: Kexue Chubanshe.

18. Hinton, I. (ed.). 2012. China's green revolution. Energy, environment and the 12th five-year plan. https://www.chinadialogue.net/UserFiles/File/PDF_ebook001.pdf.

19. Hu, Jintao. 2007. Report at 17th Party Congress. http://www.straittalk88.com/uploads/5/5/8/6/55860615 /full_text_of_hu_jintaos_report_at_17th_party_congress__qiushi_journal.pdf.

20. Hu, Jintao. 2012. Report at 18th Party Congress. http://www.china.org.cn/china/18th_cpc_ congress/2012-11/16/content_27137540.htm.

21. Hu, A. 2017. China: Innovative green development. Heidelberg: Springer.

22. Huan, Q. 2008. Growth economy and its ecological impacts upon China: A red-green perspective. The International Journal of Inclusive Democracy 4 (4). http://www.inclusivedemocracy.org/journal/vol4 /vol4_no4_qingzhi_china.htm

23. Huan, Q., (ed.). 2010. Eco-socialism as politics. Rebuilding the basis of our modern civilization. Heidelberg: Springer. 
24. Huang, P., and J. Zhang. 2015. Facts related to August 12, 2015 explosion accident in Tianjin, China. Process Safety Progress 34 (4): 313-314.

25. Jacques, M. 2012a. When China rules the world. The end of the Western world and the birth of a new global order. London: Penguin.

26. Jacques, M. 2012b. Why do we continue to ignore China's rise? Arrogance. In The Guardian/Observer. https://www.theguardian.com/world/2012/mar/25/china-rise-ignorance

27. Lambin, E.F., and P. Meyfroidt. 2011. Global land use change, economic globalization, and the looming land scarcity. Proceedings of the National Academy of Sciences of the United States of America 108 (9): 3465-3472.

28. Leach, M., I. Scoones, and A. Stirling. 2010. Dynamic sustainabilities: Technology, environment and social justice. London: EarthScan.

29. Leibold, J. 2006. Competing narratives of racial unity in Republican China. From the yellow emperor to Peking man. Modern China 32 (2): 181-220.

30. Li, H., and L. Ma. 2014. China dream. Hefei: Huangshan Publishing House.

31. Lin, J. Yifu. 2011. China and the global economy. China Economic Journal 4 (1): 1-14.

32. Lin, Delia. 2017. Civilising citizens in post-Mao China: Understanding the rhetoric of suzhi. Oxon: Abingdon; New York: Routledge.

33. Липицкий, B.C. (Lipitsky). 1984. 'Пути формирования экологической культуры личности в условиях зрелого социализма (Ways of fostering ecological culture in individuals under the conditions of mature socialism)', Вестн. Моск. ун-та. Cep. 12 (Vestnik. Mosk. Un-ta. Ser.). Теория научного коммунизма (Scientific Communism) 2.

34. Liu, S. 2003. Liu Sihua wenji (Collection of the works by Liu Sihua). Wuhan: Hubei Renmin Chubanshe.

35. Liu, Sihu. 2008. Dui jianshe shehuizhuyi shengtai wenmingde ruogan huiyi__Jianshu wode "Makesizhuyishengtai wenmingguan" (Some thoughts on the construction of socialist ecological civilization theory - Also on my 'Marxist view of ecological civilization'). Zhongguo Dizhi Daxue XuebaoSheshuikexueban (Journal of China University of Geosciences: Social Science Edition) 4.

36. Livingstone, D.N. 2007. Science, site, and speech: Scientific knowledge and the spaces of rhetoric. History of the Human Sciences 20 (2): 71-98.

37. Lu, H. (ed.). 2013. Xi explains China's reform plan. Xinhua News Agency.

38. Lu, C., Y. Dong, and J. Lian. 2016. On the concept of ecological civilization in China and Joel Kovel's ecosocialism. Capitalism Nature Socialism 27 (1): 27-31.

39. Luke, T.W. 2015. Introduction. In Telos 172: Political Critiques of the Anthropocene, http://www. telospress.com/telos-172-fall-2015-political-critiques-of-the-anthropocene/.

40. Malik, K. 2014. The quest for a moral compass: A global history of ethics. London: Atlantic Books.

41. NBS $=$ National Bureau of Statistics. 2013. Great changes in China's economic and social development since 1978. http://www.stats.gov.cn/tjgz/tjdt/201311/t20131106 456188.html.

42. Ng, Mee Kam. 2017. From the Xinhai revolution to the umbrella movement. In Insurgencies and Revolutions, eds. H. Rangan, Mee Kam Ng, L. Porter and J. Chase, 279-288. New York: Routledge.

43. Oldfield, F., T. Barnosky, J. Dearing, M. Fischer-Kowalski, J. McNeill, W. Steffen, and J. Zalasiewicz. 2014. The Anthropocene review: Its significance, implications and the rationale for a new transdisciplinary journal. The Anthropocene Review 1 (1): 1-5.

44. Palumbo, L. 2013. A post-GDP critique of the Europe 2020 strategy. Procedia - Social and Behavioral Sciences 72 (5): 47-63.

45. Pan, J. 2013a. Ensuring ecological security by adapting to carrying capacity. Social Sciences in China 34 (4): 154-161.

46. Pan J. 2013b. Building a beautiful China by listening to nature. Chinese Social Sciences Today. http://www.csstoday.com/Item/298.aspx. 1 Aug.

47. Pan, J. 2015a. How China could lead in the fight against climate change. In Our world and us: How our environment and our societies will change. Munich: Allianz SE, 96-110. https://www.allianz. com/v_1437463672000/...us/.../150114_Our_world_and_us.pdf

48. Pan, J. 2015b. Zhongguo huanjing zhili yu shengtai jianshe. Beijing: China Social Science Press. English Trans. China's Environmental Governing and Ecological Civilisation, Springer Berlin Heidelberg, Berlin, Heidelberg.

49. RMRB. 2016. Shibada yilai, Xi Jinping changshuo 25 ge reci (The 25 key phrases of Xi Jinping). http://mp.weixin.qq.com/s? biz=MjM5MjAxNDM4MA==\&mid=2666144215\&idx=1\&sn=e2d1 d59464ca568ab2a619e859dca11e\&chksm=bdb248948ac5c1828eba421 ed1a2967ecec2eafe 743eadcb8 eadc78ee8efcd7f7555ad70f1b4\&mpshare=1\&scene=5\&srcid=11150z7TokcM8TsgeHtlweQ3\#rd.

50. Sima, Qian. Burton Watson (trans.). 1993 Records of the grand historian: Qin dynasty. Hong Kong: The Chinese University of Hong Kong.

51. Steffen, W., P. Crutzen, and J. Mcneill. 2007. The Anthropocene: Are humans now overwhelming the great force of nature. Ambio: A Journal of the Human Environment 36 (8): 614-621. 
52. Tisdell, C. 2001. Globalisation and sustainability: Environmental Kuznets curve and the WTO. Ecological Economics 39 (2): 185-196.

53. UNDP, China Human Development Report. 2013. Sustainable and liveable cities: Toward ecological civilization: Beijing: China Translation and Publishing Corporation. http://www.hdr.undp. org/sites/default/files/china nhdr 2013 en final.pdf.

54. UNEP. 2016. Green is gold. The strategy and actions of China's ecological civilization. https://www. unep.org/greeneconomy/sites/unep.org.greeneconomy/files/publications/greenisgold_en_20160519.pdf.

55. Wan, J. 2012. Woguo shehuizhuanxingde daode wenhua jianshe wenti (Ethical and cultural development in China in a period of social transformation. Dangweizhongxinzu xuexi (Party Committee's Central group study), 2012, 4: 3 .

56. Wan, J. 2013. The philosophical wisdom and action implications of "Beautiful China". Social Sciences in China 34 (4): 143-153.

57. Wang, Z. 2016. The deep convergence between constructive postmodernism and Chinese Marxism. In Lamża. L. and J. Dziadkowiec. (Eds.). Recent advances in the creation of a process-based worldview: Human life in process. Newcastle upon Tyne: Cambridge Scholars, 75-93.

58. Wen, T. 2013. Baci weiji: Zhongguode zhenshi jingyan 1949-2009 (Eight crises: Lessons from China 1949-2009). Beijing: Dongfang chubanshe.

59. Wen, T., K.C. Lau, C. Cheng, H. He, and J. Qiu. 2012. Ecological civilization, indigenous culture, and rural reconstruction in China. Monthly Review 63 (9). https://monthlyreview.org/2012/02/01/ecologicalcivilization-indigenous-culture-and-ruralreconstruction-in-china

60. Wittrock, J. and R. Polt. 2016. Introduction. In Telos 177: Rethinking Nature in the Anthropocene, http://www.telospress.com/telos-177-winter-2016-rethinking-nature-in-the-anthropocene/.

61. Woetzel, J. et al. 2009. Preparing for China's urban billion, the Mackinsey Global Institute, Washington D.C. http://www.mckinsey.com/global-themes/urbanization/preparing-for-chinas-urban-billion.

62. Xi, Jinping. 2013a. Don't evaluate the performance of officials simply by GDP growth. 7 October. http://news.xinhuanet.com/world/2013-10/07/c_117609149.htm.

63. Xi, Jinping. 2013b. Communique of the Third Plenum of the $18^{\text {th }}$ Central Committee of the CPC. http://www.china.org.cn/china/third_plenary_session/2014-01/15/content_31203056.htm.

64. Xi, Jinping. 2014. Xi Jinping: The governance of China. Beijing: Foreign Languages Press.

65. Xi, Jinping. 2017. Xi Jinping delivers report to CPC congress. http://www.chinadaily.com.cn/china/19 thcpcnationalcongress/2017-10/18/content 33398037.htm.

66. Yan, G., and Z. Yang. 2009. Shengtai wenmingde lilun yu xitong jianshe (Constructing a theory and system of ecological civilization). Beijing: Zhongyang bianyi chubanshe.

67. Ye, Q. 1982. Shengtai nongye (ecological agriculture), Nongye jingji wenti (Questions of agricultural economy), 11 .

68. Ye, Q. 1988. Shengtai nongye: Nongye de weilai (Ecological agriculture: The future of agriculture). Chongqing: Chongqing Chubanshe.

69. Ye, Q. 2004. Ye Qianji wenji (The collected works of Ye Qianji). Sheke wenxian chubanshe.

70. Zalasiewic, A., M. Williams, W. Steffen, and P. Crutzen. 2010. The new world of the Anthropocene. Environmental Science and Technology 44 (7): 2228-2231.

71. Zhang, S. 1985. Zai chengshu shehuizhuyi tiaojianxia peiyang geren shengtai wenmingde tujing (Cultivating the way of individual ecological civilization under the condition of mature socialism), Guangming Ribao.

72. Zhang, J.Y., and M. Barr. 2013. Green politics in China: Environmental governance and state-society relations. London: Pluto.

Maurizio Marinelli is a Senior Lecturer (Associate Professor) in East Asian History and Co-Director of the Asia Centre at the University of Sussex. He is also a Visiting Senior Research Associate at the Institute for Global Prosperity, The Bartlett, University College of London. The focus of his research is located at the crossroads of Chinese history, politics and society. Through this interdisciplinary lens, the exploration of political, cultural and socio-spatial transformation in China becomes a means by which to engage with larger related universally experienced themes, such as: the connections between colonial and global cities, citizenship construction, and the Chinese political and intellectual debates on public value, prosperity and ecological civilisation. His research has been published in various journals, including Theory and Society, China Information, Cultural Studies Review, Journal of Chinese Current Affairs, Postcolonial Studies, Urban History. 